\title{
極小 IC タグとその応用展開
}

\section{1.はじめに}

IC タグは IC に記録した情報を，非接触で「読み取り」 または「読み取りと書換え」ができる夕グ（荷札）である。 高周波で質問機（リーダ） と交信する夕グであることから, RFID（Radio Frequency Identification）や電子夕グとも 呼ばれている. 日本では 1980 年代からファクトリーオー トメーションなどで実用化されてきた。その後の進歩に よって IC の小型化・高性能化・低価格化が進み，取付け られる「モノ」の対象が広がっている。また，情報ネット ワークとの融合によって新たな活用が考えられ，ユビキタ スネットワーク社会の基盤ツールとなることが期待されて いる1).

IC タグはすでに多数，開発・実用されているが，本稿 では，固有番号のみを記録し，属性データはすべてネット ワークで管理されるタイプの極小 IC タグを取り上げ，そ の特徴と応用について弊社のミューチップを例に解説する.

\section{2. ミューチップの概要}

ミューチップは $0.4 \mathrm{~mm}$ 角の世界最小クラスの IC タグ 用チップである2). 図 1 に指先に乗せたミューチップの外 観写真を示す.

ミューチッブは，128ビットの番号（ミューチップ ID） のみを ROM（Read Only Memory）に記録しており，他 のデー夕の書き込みはできない。この ID は製造時に ROM に書き込む固有の番号であり,書換えも不可能である. 128 ビットは，10 進法で 38 桁の数值である。このうち約 100 ビット（10 進法で 30 桁）を商品などの識別用に使用でき る。これは，世界中で 60 億人が毎日 1 億個のモノに発行 し続けても，ID を使い切るまでには，50 億年以上かかる 計算になる.

外部アンテナを装着した例を図 2 に示す。外部アンテナ とチップの組立て方法は、3 種類を開発した。WB タイプ ではアンテナ材として用いたリードフレームへのダイボン ドと金ワイヤボンディングによって、TCP タイプではポ リイミドフィルム上に形成した銅篂と錫めっきにチップ上 の金めっきバンプを熱圧着することによって接合する。印

\footnotetext{
* Kanda, Naoya

(株)日立製作所生産技術研究所 実装ソリューション研究部 横浜市戸塚区吉田町 292（开244-0817） 2004.3. 4 受理
}

諫 田 尚 哉*

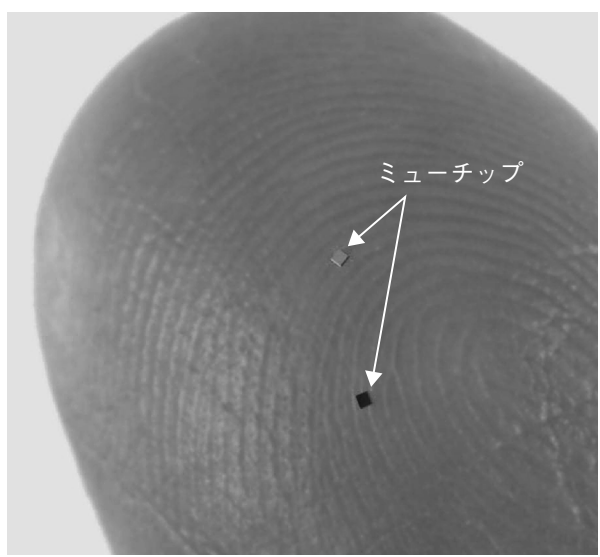

図 1 ミューチップの外観

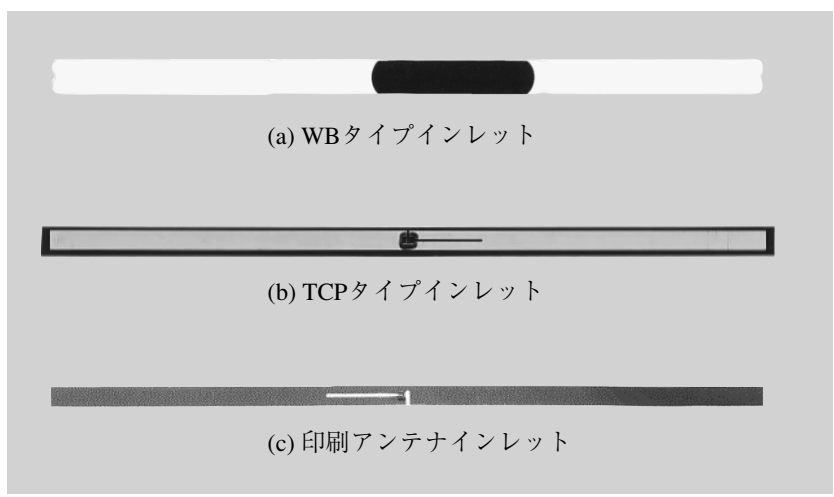

図 2 外部アンテナを装着したインレット例

刷アンテナでは、アンテナのアルミ材とチップ上の金めっ きバンプを超音波加振により接合している。現在製造して いる TCP インレットのサイズは，長さ約 $70 \mathrm{~mm} \times$ 幅 3 $\mathrm{mm} \times$ 厚さ $0.22 \mathrm{~mm}$ である.ミューチップに比べると大 きなアンテナであるが，照射されるマイクロ波の波長と必 要な利得から長さが決定されている.

図 3 にはミューチップを使ったシステムの基本構成例を 示した。リーダがリーダ側アンテナを介してミューチップ に2.45 GHz のマイクロ波を照射すると，受信したマイク ロ波から動作用電力を生成し，ミューチップIDを返信す る. 交信可能な距離は，現在のところ理想的条件下で最大 $30 \mathrm{~cm}$ 程度である．ただし，対象物に埋め込んで使用する 場合は，その材質や厚さによってマイクロ波が反射，吸収 される場合もあるため，交信距離は短くなる．また，アン 


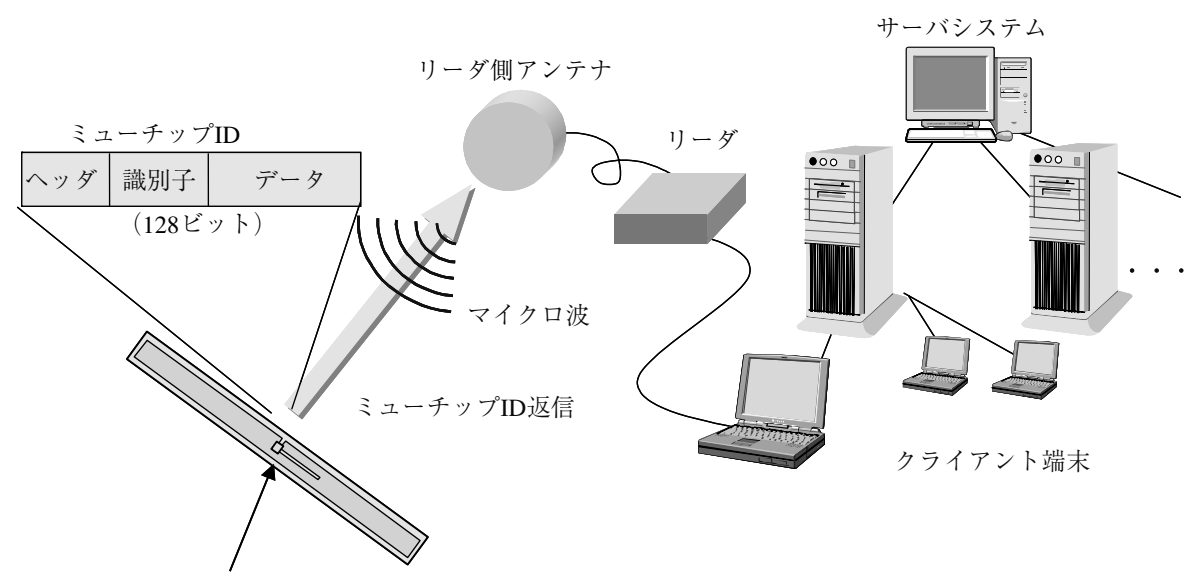

外部アンテナ付きミューチップ

図 3 ミューチップを使ったシステムの基本構成例

テナ周辺の誘電率が自由空間に比べて高くなるので, 材質 に応じてアンテナ長を適切に選択することが必要な場合も ある。

読み取られたミューチップ ID は単なる番号にすぎない が，サーバーシステムに構築されたデータベースによって 属性情報と関連付けられ，さまざまなアプリケーション上 で活用することができる．また，従来のバーコードでは， 同じ「商品名」の品物には同じコードしか付けることがで きなかったが，ミューチップではひとつひとつに異なる ミューチップID がついているので，商品の「個品管理」 を実現する高度なデータベースの利用が可能となる.

\section{3. ミューチップの開発}

\section{1 ミューチップが目指したもの}

バーコードは, 光学的読み取りのために対象物表面への 印刷・貼付が必要であり, 污染等によって読み取り不能に なることが欠点として挙げられる.しかし，コスト負担が 圧倒的に低く，広く活用されている.

他方, 従来の IC タグは, タグが大きく, 単価（およそ 100 円から数千円）が高いことから取付け対象が限られ, 再利用を前提にした分野で利用されることが多かっだ

ミューチップは, バーコードや従来の IC タグが適用で きない分野を狙って開発したもので，バーコードよりも多 くの情報量を保持でき, 従来の IC 夕グよりも小さく, 安 価に提供することを目標としている.

\subsection{IC の機能選択}

ミューチップを極小サイズに収めるためには，IC タグ として半ば常識化している機能の全てを盛り込むことは困 難である。 そこで, 従来 IC 内に取り达んでいた機能のう ち, 情報ネットワークで代替できる機能は削除し, 低価格 タグとして必要不可欠な機能のみを残す方針とした。この 結果，ミューチップは，128 bitの ID 番号を記録し再生す るためのデジタル回路と, 通信のためのマイクロ波を処理 するアナログ回路のみから構成することとした。図 4 に, ミューチップの主要なブロック回路図を示す.

アナログ回路は, デジタル回路を動作させるための電力 を生成する整流回路 (Power rectifier), リセット回路 (Power-on reset), クロック抽出回路（Clock extraction）

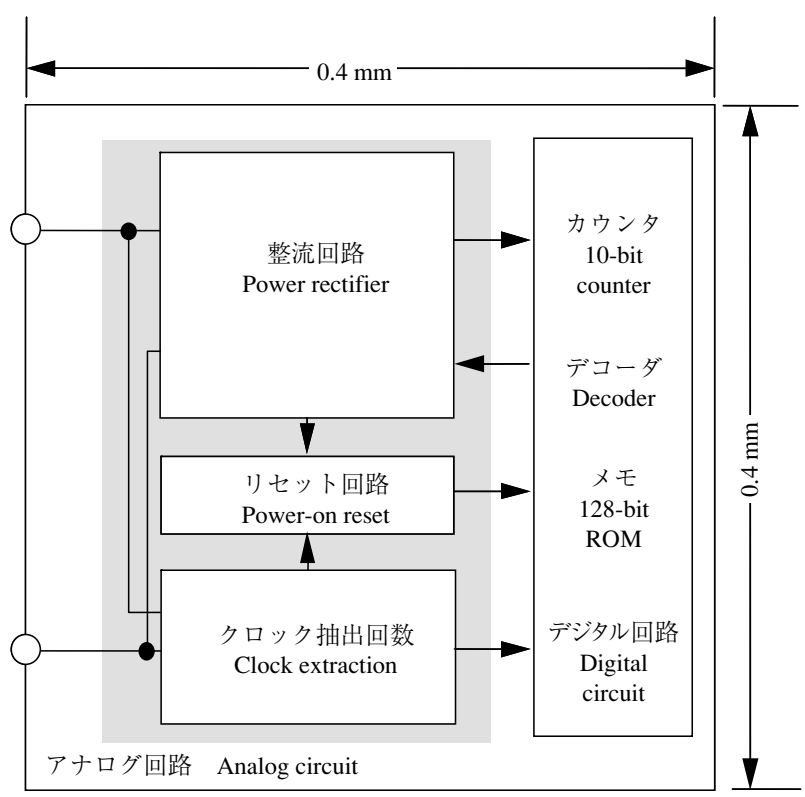

図 4 ミューチップの主要ブロック回路図

が主要なものである.この他， $2.4 \mathrm{GHz}$ マイクロ波により 電池なしで CMOS 半導体を動作させるため, MOSトラン ジスタゲート酸化膜で $100 \mathrm{pF}$ キャパシタを形成し電源と している。

ROM は半導体メモリとしては小さい 128 bit とした. ID 番号の空間としては前記したように膨大なものである.メ モリ周辺回路のカウンタも最小限（10-bit Counter）に抑 え，小形化を実現している.

従来の IC タグでは, 書き込み機能によってデー夕を分 散化することや, サーバコンピュータとは独立してオフラ インでIC夕グのデータ読み取り, 書き込みを実行するこ とで, サーバコンピュータやデータベースの負荷を低減す る努力が払われてきた。 しかし，個々の対象物を正確に管 理するためには, IC タグの故障などに備えるため, 書き 込んだデータと同じデータをサーバコンピュータ側にも蓄 積することが必要である. そのため, 結局は, IC夕グに データを分散させたとしてもサーバコンピュータの負荷低 減にはなりにくいのである。 


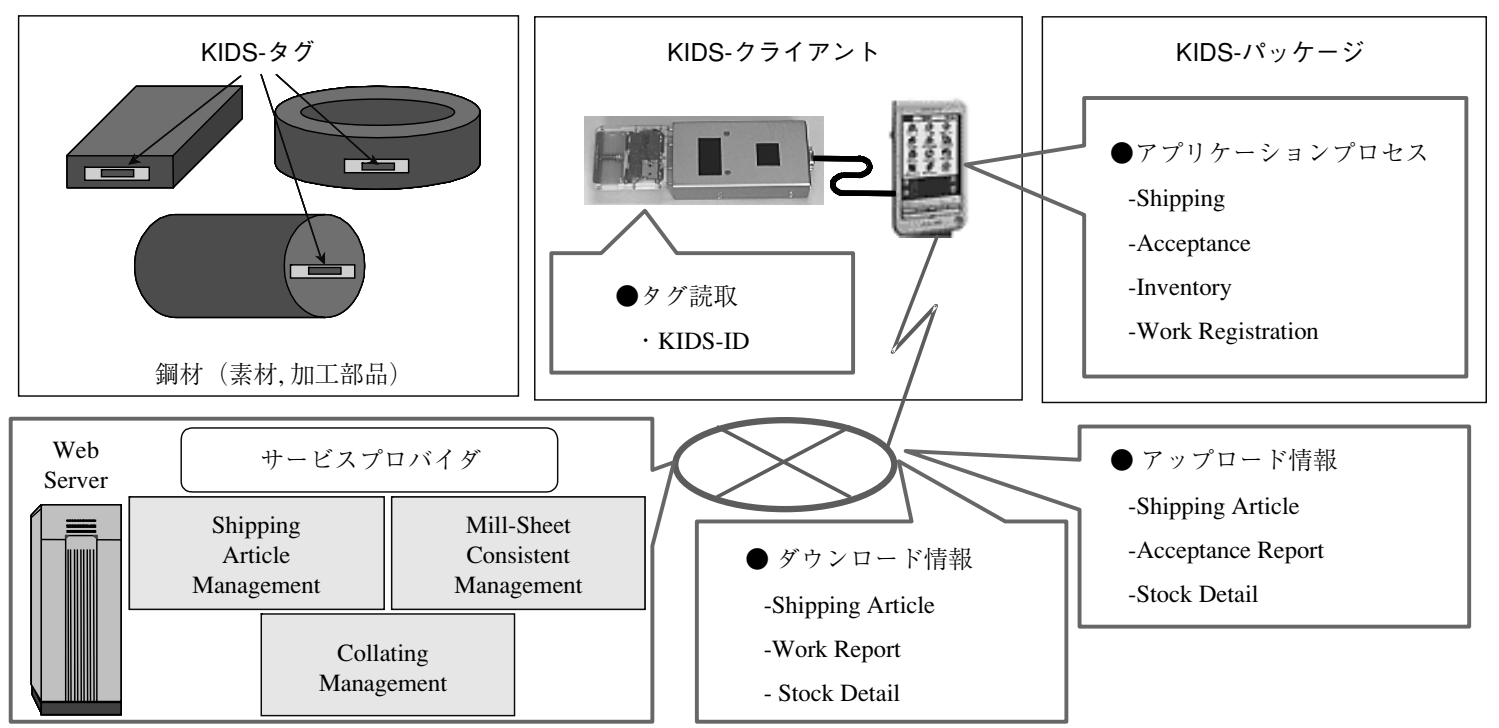

図 5 ミューチップを利用した鋼材管理システム例 KIDS

また，食品のトレーサビリテイ向上を目的にリアルタイ ムに所在を管理するニーズが高まっているが，そのために は, 所在管理のチェックポイントから IC タグにアクセス するたびごとに，コンピュータネットワークを介してサー バコンピュータにチェックポイント情報, IC タグ情報を 登録することが必須となっている.

上記のような事情から，IC タグを活用する市場では情 報ネットワークを活用することが必然となっており，IC タグへのデー夕書き込み機能は必ずしも必要ではないと判 断した．IC タグの故障に対する備えが不要な場合, ある いは，リアルタイムな所在管理が不要な場合であっても， 数量の圧倒的に多い夕グのコストを低減させた方が, シス テム全体のコスト低減に有利であると考え, IC 夕グの徹 底した小型・低価格化を進めたのである.

また, 一般的に, 書き込み可能メモリは, 摂氏 200 度程 度の高温度にさらされるとデータが変化する，いわゆる 「デー夕化け」や，デー夕が揮発する可能性が高まる. ミューチップの ROM は，製造時に設定され書換えも不可 能であるので，デー夕化けや揮発に対して高い信頼性を有 している.

輻輳制御機能は複数の IC タグを短時間で読み取るため に考え出された機能であるが，夕グの配置や読み取り環境 の影響で充分な性能が出ないことがある。例えば，リーダ 側アンテナから見て, 複数の IC タグが重なった場合は電 波の影ができてしまうため，影に入った IC タグは輻輳制 御機能があったとしても読み取ることができない。そのた め, 対象物を整列させたりする工夫が必要となる.

現行のミューチップは, 輻輳制御機能を持たないが, 読 み取りやすいように対象物を整列した上で，リーダ側アン テナを移動させたり, 対象物を整列させたままアンテナ上 を移動させることにより, 確実に個品認識をしながら複数 のミューチップを連続的に読み取ることが可能である.

多数の対象物に装着したIC夕グを,一つの抜けも無く読 み取ることが要求される場合は, 輻軑制御機能に頼るだけ でなく，ある程度整列した上で読み取るほうが確実であり， トータルの運用コストを低減できる場合が多いのである.

\section{4. ミューチップの応用}

ミューチップは, 小型で個別の ID を持つこと, 無線通 信により認識されることなどの特徵を生かして，さまざま なソリューションを実現することができる，以下に応用例 を二例紹介する.

\section{1 鋼材管理システム KIDS（Kouzai Identification System $^{4)}$ ).}

概要を図 5 に示す。ミューチップインレットを柔軟性が ある樹脂に埋め込んだ KIDS タグ（KIDS-tag）を鋼材に 貼り付けて，鋼材の個品管理を実現するものである.

KIDS 夕グを金属に貼り付けると, リーダからのマイク 口波が金属の影響を受けて交信距離が低下するが，専用 リーダと携带情報端末からなる KIDS クライアントでは, 確実にミューチップ ID を読み取ることができる. KIDS タグは，錆，金属粉，泥などの污れが付着していても，問 題なくKIDS クライアントによって読み取ることができる.

KIDS クライアントとサービスプロバイダのサーバ （Web Server）とは，無線LANなどによって通信する. 出荷, 入荷, 棚卸, 加工時に KIDS クライアントによって 鋼材現品ごとの情報を登録, 参照することができる. KIDS により，各作業の効率化が実現できるだけでなく, SCM (Supply Chain Management) を構築することも可能で ある。

KIDS タグは，鋼材に貼り付けることを想定して開発し たが，鋼材に限らず，他の金属表面に貼り付けて利用する こともできる. 図 6 に, PDA に貼り付けた例を示す. KIDS タグには鋼材㙋り付け用強力接着剂を塗布してあり, 容易 に金属表面に貼り付けることができる．KIDS タグの大き さは, 図 2 に示したインレットとほほ同じ大きさなので, 積み上げて保管されることの多い鋼材の側面にも貼り付け ることができる. KIDS タグの表面には，ミューチップの 故障時のために，独自の ID が印字されている.ミューチッ プの故障時には, 印字されたID を手がかりにして, 対象 の鋼材情報をサーバコンピュータ上で新しいKIDS タグに 引き継ぐことができる. 


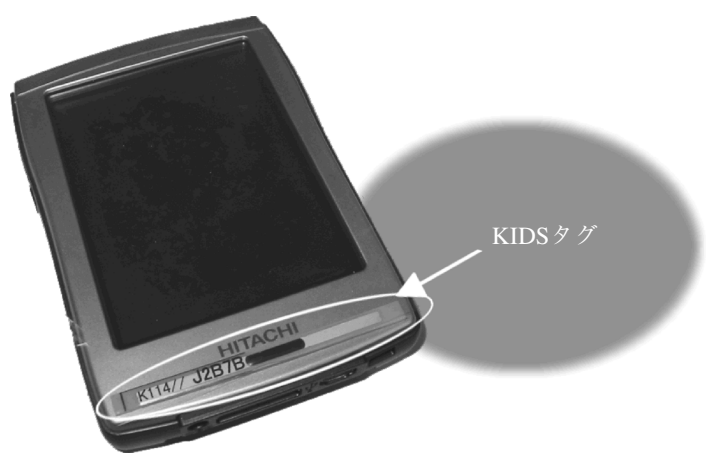

図 6 KIDS タグの応用例

\section{2 『愛・地球博』入場券システム ${ }^{5}$}

2005 年 3 月 25 日から 9 月 25 日の 185 日間， 2005 年日 本国際博覧会 (愛知万博) - 通称「愛・地球博」が名古屋 東部丘陵（長久手町・豊田市・瀬戸市）を会場として開催 される.

通常の入場券では磁気ストライプや印刷の目視によって 有効かどうかを確認するのが一般的であるが，大量の前売 $り$ 入場券が開催の 1 年以上前から販売される本博覧会では, 磁気ストライプや目視だけでは不正入場を防げないと予想 された。正規入場者の円滑で安全な入場と, 偽造防止を両 立するために各種の電子的な機器・コードによる検討がな され，その結果，

・IC 夕グ技術への注目

・紙製入場券利用に耐えうる機能

・新規技術性

が評価され，ミューチップが採用されることになった。

本システムは入場券の入場者管理のためにミューチップ に書き込まれた ID と入場券番号をリンクさせデータベー ス化し，このIDをべースとした入場者管理システムを構 築しておくことで, 人手に頼らず電子的かつ無線の認識技 術により入場者管理を行うことを主目的としている.

ミューチップ ID はユニークな固有番号で構成されてい るため各入場券の個別識別が可能であり, 再入場や後日入 場の排除をシステム上で実現している。また，来場入場者 数は ID 数を即時にチェックすることにより自動集計でき るので, 混雑具合を踏まえた安全で快適な運営を可能にす ると期待される。

ミューチップ ID は各入場券の識別が可能ではあるが, 記録されている情報は固有番号のみであるため，これを解 読しても入場券の属性は判別できないし，ROM であるた
め書き換えもできない．これは，言い換えると入場券に付 与された情報からだけでは入場可否の情報は何も解らない ことを意味しており，偽造防止やセキュリテイ向上に大き な役割をはたしている.

入場券の発行総数は約 2 千万枚が計画されており, IC 夕グの実用事例としてこれだけ大規模な事例は数少ない.

入場券を IC タグとして応用したさまざまな付加サービス も検討されており, 利便性を実感することのできるフィー ルドとなる期待がある.

\section{5.終わりに}

極小 IC タグの一例として，ミューチップの概要，開発， および応用について紹介した。昨今は，食品のトレーサビ リティ向上やセキュリティの向上に関心が高まり, IC 夕 グを積極的に活用しようとする動きも出てきている。他方， 情報ネットワークのセキュリティや個人のプライバシー保 護についても意識が高まりつつあり, ユビキタスネット ワーク社会での IC タグ高度利活用に向けた議論の環境は 整ってきていると感じる. 充分な議論に基づいて, 既存の バーコードや IC タグをうまく活用し, 無駄の少ない先進 国として世界をリードする好機と期待している，そのため にも，ハードウェア技術の高度化を進めるとともに, IC タグの利便性を実感しながら社会的なコンセンサスを醇成 することによって，広く活用の知恵を集める時期にあると 思われる。

\section{参 考 文 献}

1）総務省 HP http://www.soumu.go.jp/s-news/2004/ pdf/040223_2_bt21.pdf

2 ) Takaragi, K., Usami, M., Imura R., Itsuki, R. and Satoh, T. : An Ultra Small Individual Recognition Security Chip, IEEE Micro, Institute of Electrical and Electronics Engineers, 21 (6), 43 (November/December 2001)

3 ) Finkenzeller, Klaus: “RFID HANDBOOK : RadioFrequency Identification Fundamentals and Applications", translated by Rachel Waddington (1999), John Wiley \& Son, Ltd

4 ）日立製作所 HP http://www.hitachi.co.jp/Prod/muchip/p 00054.html

5 ） 2005 年日本国際博覧会 HP http : //www-0.expo2005. or.jp/jp/ticket/ic.html 